\title{
Catalytic Complete Oxidation Of Benzene Over Pd Catalysts: Support Effect
}

\author{
Tatyana Tabakova ${ }^{1}$, Petya Petrova ${ }^{1}$, Yordanka Karakirova ${ }^{1}$, \\ Anna Maria Venezia ${ }^{2}$, Leonarda Francesca Liotta ${ }^{2}$, Lyuba Ilieva ${ }^{1}$ \\ ${ }^{1}$ Institute of Catalysis, Bulgarian Academy of Sciences, Acad. G. Bonchev Str. Bl. 11, 1113 Sofia, Bulgaria \\ tabakova@ic.bas.bg; petia@ic.bas.bg; daniepr@ic.bas.bg; luilieva@ic.bas.bg; \\ ${ }^{2}$ Istituto per lo Studio dei Materiali Nanostrutturati, CNR, 90146 Palermo, Italy \\ annamaria.venezia@cnr.it; leonardafrancesca.liotta@cnr.it
}

\begin{abstract}
In this paper, the effect of various supports on complete benzene oxidation over Pd catalysts was studied. Benzene was selected as a representative model of volatile organic compounds (VOCs) because it is among the most emitted air pollutants with toxic and carcinogenic nature. Complete catalytic oxidation is a very effective and environmentally-friendly approach for the destructive removal of VOCs from waste gas streams due to the opportunity for a total conversion to $\mathrm{CO}_{2}$ and water at relatively low temperatures. The rational design of catalytic materials with improved efficiency in the elimination of VOCs attracts a substantial interest in the field of environmental catalysis because efficient catalysts should combine high activity with economic feasibility. The aim of the present work was the development of Pd-based catalytic materials with high benzene oxidation activity by using appropriate and economically profitable supports. Two metal oxides, namely $\mathrm{Al}_{2} \mathrm{O}_{3}$ and $\mathrm{CeO}_{2}$ were selected, considering the cost-effectiveness of alumina and the beneficial role of ceria in VOCs oxidation. Additionally, high surface area alumina was modified by finely dispersed ceria nanoparticles. The effect of Y-doping of alumina-supported ceria on the activity of Pd catalyst was also studied. Catalytic measurements revealed the best performance of Pd catalyst on Y-doped $\mathrm{CeO}_{2}$ supported on $\mathrm{Al}_{2} \mathrm{O}_{3}$. The sample exhibited complete benzene conversion at $175{ }^{\circ} \mathrm{C}$ and high stability during 24 hours in a stream. The favorable role of $\mathrm{Y}$-doping in improved oxygen mobility of ceria was evidenced by X-ray photoelectron spectral analysis. A line with g-value 1.964 , assigned to $\mathrm{Ce}^{3+}$, was registered in the EPR spectrum of the sample after catalytic test, focusing on the possible role of $\mathrm{Ce}^{3+}$ in oxygen activation. This catalytic material demonstrated the potential to meet the challenging emission regulations in an effective and economically profitable way.
\end{abstract}

Keywords: VOCs abatement, complete benzene oxidation, Pd catalyst, $\mathrm{Al}_{2} \mathrm{O}_{3}$-supported ceria, $\mathrm{Y}$-doping

\section{Introduction}

The increasing levels of air pollution represent a serious concern about the environment and human health. Volatile organic compounds (VOCs) are proved as significant contributors to air pollution due to their harmful nature. Complete catalytic oxidation has a high potential for the destructive removal of VOCs from waste gas streams. It is a very effective and environmentally-friendly approach that allows for the total conversion of VOCs to $\mathrm{CO}_{2}$ and water at relatively low temperatures. The development of catalytic materials with improved efficiency in the elimination of VOCs is currently one of the scientific challenges. It has attracted substantial interest in the field of environmental catalysis because efficient catalysts should combine high activity with economic feasibility [1-3]. Two major types of catalysts, namely noble metalbased and transition metal oxides are currently most intensively studied to meet the challenging environmental regulations [4]. The comparison reveals that the noble metals exhibited superior activity at lower temperatures than transition metal oxides [5]. Pd-based catalysts are recognized as very suitable for VOCs oxidation [6,7]. However, the proper selection of support is of particular importance for the catalytic performance due to the participation of reducible supports in catalytic action, as well as in the stabilization of noble metal particles, thus preventing sintering and deactivation. Moreover, the use of low-cost materials is relevant from an economic point of view. Alumina is one of the most studied supports for Pd [5, 8]. Complete benzene oxidation (CBO) over $\mathrm{Pd} / \mathrm{Al}_{2} \mathrm{O}_{3}$ catalyst, in particular the effects of pretreatment atmospheres, has been investigated [9]. The favorable role of basic sites of support on toluene and isopropyl alcohol oxidation activity of $\mathrm{Pd} / \mathrm{Al}_{2} \mathrm{O}_{3}$ has been demonstrated by doping with $\mathrm{MgO}, \mathrm{BaO}$ and $\mathrm{ZrO}_{2}$ [10]. Gil et al. have prepared Pd catalysts supported on various metal oxides $\left(\mathrm{CeO}_{2}, \mathrm{TiO}_{2}, \mathrm{Al}_{2} \mathrm{O}_{3}\right)$ and alumina doped by oxides of $\mathrm{Ce}, \mathrm{Ti}, \mathrm{Fe}, \mathrm{Mn}$ [11]. A strong effect on the 
oxidation state of $\mathrm{Pd}$ species and the propene oxidation activity has been found. In contrast to the low activity of $\mathrm{Pd} / \mathrm{CeO} 2$ due to the interaction of $\mathrm{Pd}^{4+}$ species with the support, the modification of alumina by $5 \mathrm{~mol} . \% \mathrm{CeO}_{2}$ has produced catalyst with improved performance attributed to the enhanced metal-support interactions and availability of highly dispersed Pd particles. Ren et al. have observed a positive role of the addition of $\mathrm{CeO}_{2}$ on toluene oxidation activity of $\mathrm{Pd} / \mathrm{Al}_{2} \mathrm{O}_{3}$ [12]. The abundance of oxygen vacancies and active oxygen species on the catalyst surface due to the facile transfer $\mathrm{Ce}^{3+} \leftrightarrow \mathrm{Ce}^{4+}$ resulted in a decrease of $\mathrm{T}_{90}$ (temperature for $90 \%$ conversion) of $\mathrm{Pd} / \mathrm{Ce}-\mathrm{Al}_{2} \mathrm{O}_{3}$ by $40{ }^{\circ} \mathrm{C}$. Recently, we tuned ceria support properties by $\mathrm{Y}$-doping $\left(1 \mathrm{wt} . \% \mathrm{Y}_{2} \mathrm{O}_{3}\right)$ and analyzed the $\mathrm{CBO}$ of supported mono and bimetallic Au-Pd catalysts [13]. Despite the various supports, Pd-based catalysts exhibited higher activity as compared to the corresponding Au-based.

The aim of the present work was the development of Pd-based catalytic materials with high benzene oxidation activity by using appropriate and economically profitable supports. Two metal oxides, namely $\mathrm{Al}_{2} \mathrm{O}_{3}$ and $\mathrm{CeO}_{2}$ were selected, considering the cost-effectiveness of alumina and the favourable role of $\mathrm{CeO}_{2}$ in VOCs oxidation. Then, high surface area alumina was modified by finely dispersed ceria nanoparticles. The effect of Y-doping of alumina-supported ceria on the activity of supported Pd catalyst was also studied. Benzene was selected as a representative model of VOCs because, among the most emitted pollutants, known as BTX (Benzene, Toluene, and Xylene) is very stable and difficult to oxidize.

\section{Experimental}

\subsection{Samples preparation}

Ceria was lab-prepared by using an aqueous solution of $\mathrm{Ce}\left(\mathrm{NO}_{3}\right)_{3} \cdot 6 \mathrm{H}_{2} \mathrm{O}$ as precursor and $\mathrm{Na}_{2} \mathrm{CO}_{3}$ as precipitant. The synthesis was carried out at $60{ }^{\circ} \mathrm{C}$ and $\mathrm{pH}=9.0$. The precipitate was aged at the same temperature for $1 \mathrm{~h}$, washed with distilled water until the absence of $\mathrm{NO}_{3}{ }^{-}$ions and dried at $80{ }^{\circ} \mathrm{C}$. Finally, cerium hydroxide was subjected to thermal treatment at $400^{\circ} \mathrm{C}$ for 2 hours. Ceria $\left(30 \mathrm{wt} . \% \mathrm{CeO}_{2}\right)$ was supported on commercial $\gamma-\mathrm{Al}_{2} \mathrm{O}_{3}$ (Sasol) by mechanochemicall mixing of alumina and cerium hydroxide and calcination at $400{ }^{\circ} \mathrm{C}$. The amount of cerium hydroxide was calculated based on analysis of weight losses during cerium hydroxide treatment at $400{ }^{\circ} \mathrm{C}$. The Y-doping of ceria was performed following the procedure for alumina-supported ceria with the addition of $\mathrm{Y}_{2} \mathrm{O}_{3}(1 \mathrm{wt} . \%$ in respect to the ceria content).

Deposition-precipitation method was applied for the preparation of supported Pd samples. All samples contain $1 \mathrm{wt} . \%$ $\mathrm{Pd}$. Before the deposition, all supports were dispersed in water by ultrasound. The interaction between $\mathrm{Pd}\left(\mathrm{NO}_{3}\right)_{2} \cdot \mathrm{xH}_{2} \mathrm{O}$ and $\mathrm{Na}_{2} \mathrm{CO}_{3}$ was carried out at $\mathrm{pH}=7.0$, temperature $60{ }^{\circ} \mathrm{C}$ and stirring speed $=250 \mathrm{rpm}$. After aging at the same temperature for $1 \mathrm{~h}$, the solids were carefully washed, dried and calcined at $400^{\circ} \mathrm{C}$.

\subsection{Samples characterization}

Textural characteristics of the catalysts were estimated by nitrogen adsorption/desorption experiments carried out by using a Micromeritics ASAP 2020. The specific surface areas were determined from $\mathrm{N}_{2}$ adsorption-desorption isotherms at $-196{ }^{\circ} \mathrm{C}$ and calculated through the Brunauer -Emmett-Teller (BET) method at pressure range 0.05-0.3 P/ $/ \mathrm{P}_{0}$. The mean pore size diameter and total pore volume were calculated by BJH method applied to the desorption branch. Prior to the measurements, the samples were degassed at $250^{\circ} \mathrm{C}$ for $2 \mathrm{~h}$.

Powder X-ray diffraction (PXRD) data were recorded on PANalytical Empyrean apparatus equipped with a

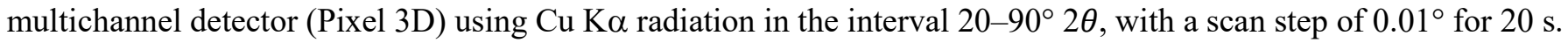

X-ray photoelectron spectroscopy (XPS) measurements were performed using VG Microtech ESCA 3000 Multilab, equipped with a dual $\mathrm{Mg} / \mathrm{Al}$ anode. The spectra were excited by the unmonochromatized $\mathrm{Al} \mathrm{K} \alpha$ source (1486.6 eV) run at $14 \mathrm{kV}$ and $15 \mathrm{~mA}$. Analyses of the peaks were carried out with the Casa XPS software.

Temperature-programmed reduction (TPR) experiments were carried out in a flow system with $\mathrm{H}_{2}$ - Ar gas mixture $\left(10 \% \mathrm{H}_{2}\right)$ at a flow rate of $24 \mathrm{ml} / \mathrm{min}$ over sample amount $0.05 \mathrm{~g}$. The temperature ramp rate was $15{ }^{\circ} \mathrm{C} / \mathrm{min}$. The water (product of reduction) was removed in a cooling trap $\left(-40^{\circ} \mathrm{C}\right)$ installed before the thermal conductivity detector

Electron paramagnetic resonance (EPR) spectra were collected on a JEOL JES-FA 100 EPR spectrometer operating in frequency $9.5 \mathrm{GHz}$ (X-band), equipped with a standard $\mathrm{TE}_{011}$ cylindrical resonator. The spectra were recorded at modulation frequency $100 \mathrm{kHz}$, microwave power $1 \mathrm{~mW}$ and modulation amplitude $0.2 \mathrm{mT}$. 


\subsection{Catalytic activity measurements}

The catalytic tests were performed in a flow fixed bed reactor under the following conditions: catalyst amount -0.5 $\mathrm{cm}^{3}$ with particles size $0.25-0.50 \mathrm{~mm}$, temperature range $100-300{ }^{\circ} \mathrm{C}$, inlet benzene concentration $42 \mathrm{~g} / \mathrm{m}^{3}$ in air, space velocity $4000 \mathrm{~h}^{-1}$. Gas chromatograph Hewlett Packard 5890 (Agilent 5890A series II) with flame ionization detector and capillary HP Plot Q column was used for the analysis of the products. The sample activation was carried out "in situ" in a flow of purified air at $350{ }^{\circ} \mathrm{C}$ for $1 \mathrm{~h}$.

\section{Results and discussion}

\subsection{Catalytic measurements}

The results of complete benzene oxidation over Pd-based catalysts are listed in Table 1.

Table 1: Degree of benzene conversion at different temperatures.

\begin{tabular}{|c|c|c|c|c|c|c|}
\hline Sample & $\begin{array}{c}\text { Conversion } \\
\text { at } 100{ }^{\circ} \mathrm{C} \\
\%\end{array}$ & $\begin{array}{c}\text { Conversion } \\
\text { at } 150{ }^{\circ} \mathrm{C} \\
\%\end{array}$ & $\begin{array}{c}\text { Conversion } \\
\text { at } 175^{\circ} \mathrm{C} \\
\%\end{array}$ & $\begin{array}{c}\text { Conversion } \\
\text { at } 200{ }^{\circ} \mathrm{C} \\
\%\end{array}$ & $\begin{array}{c}\text { Conversion } \\
\text { at } 250{ }^{\circ} \mathrm{C} \\
\%\end{array}$ & $\begin{array}{c}\text { Conversion } \\
\text { at } 300{ }^{\circ} \mathrm{C} \\
\%\end{array}$ \\
\hline $\mathrm{Pd} / \mathrm{Al}_{2} \mathrm{O}_{3}$ & 86 & 89 & 91 & 93 & 94 & 95 \\
\hline $\mathrm{Pd} / \mathrm{CeO}_{2}$ & 71 & 76 & 88 & 89 & 90 & 90 \\
\hline $\mathrm{Pd} / \mathrm{CeO}_{2}-\mathrm{Al}_{2} \mathrm{O}_{3}$ & 50 & 92 & 96 & 97 & 98 & 100 \\
\hline $\mathrm{Pd} / \mathrm{Y}-\mathrm{CeO}_{2}-\mathrm{Al}_{2} \mathrm{O}_{3}$ & 91 & 99 & 100 & 100 & 100 & 100 \\
\hline
\end{tabular}

The sample $\mathrm{Pd} / \mathrm{Y}-\mathrm{CeO}_{2}-\mathrm{Al}_{2} \mathrm{O}_{3}$ demonstrated superior activity. Complete benzene conversion was achieved at $175{ }^{\circ} \mathrm{C}$. Intermediate products of partial oxidation were not detected during $24 \mathrm{~h}$ stability test at this temperature. $\mathrm{Pd} / \mathrm{CeO}_{2}-\mathrm{Al}_{2} \mathrm{O}_{3}$ exhibited also high activity with $96 \%$ conversion at $175{ }^{\circ} \mathrm{C}$, achieving total conversion at $300{ }^{\circ} \mathrm{C}$. The temperature dependence of $\mathrm{CBO}$ in the low-temperature range is presented in Fig. 1.The effect of Y-doping of ceria is clearly shown by comparing the degree of benzene conversion at $175{ }^{\circ} \mathrm{C}$. It is worth noting that the deposition of $\mathrm{Pd}$ on inert $\mathrm{Al}_{2} \mathrm{O}_{3}$ resulted in a relatively high activity of $\mathrm{Pd} / \mathrm{Al}_{2} \mathrm{O}_{3}$ catalyst $\left(86 \%\right.$ conversion at $\left.100{ }^{\circ} \mathrm{C}\right)$. The explanation could be related to the ability of $\mathrm{PdO}$ to provide active oxygen. Initial $\mathrm{Pd}^{2+} \mathrm{O}^{2-}$ reduction by benzene followed by $\mathrm{Pd}^{0}$ oxidation with $\mathrm{O}_{2}$ and $\mathrm{Pd}^{2+} \mathrm{O}^{2-}$ recovering have been proposed by $\mathrm{He}$ at al. studying $\mathrm{Pd} /$ zeolites catalysts [14]. However, in the present case $100 \%$

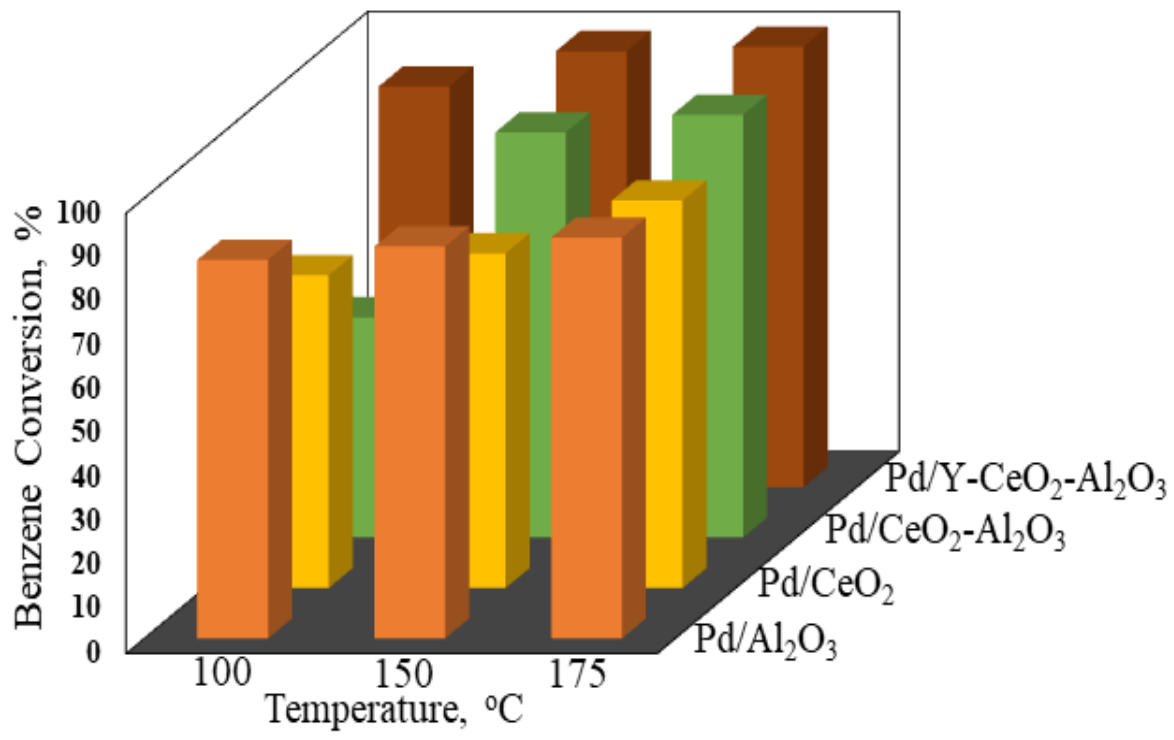

Fig. 1: Temperature dependence of CBO over the studied catalysts. 
conversion was not attained even at $300{ }^{\circ} \mathrm{C}$ over $\mathrm{Pd} / \mathrm{Al}_{2} \mathrm{O}_{3}$. It could be suggested that the observed best performance of $\mathrm{Pd} / \mathrm{Y}-\mathrm{CeO}_{2}-\mathrm{Al}_{2} \mathrm{O}_{3}$ catalyst originated from the oxidation activity of both PdO dispersed on alumina and PdO located on ceria or Y-doped ceria phase with the important contribution of ceria phase in the oxygen supply.

\subsection{Sample characterization}

Textural characteristics, namely specific surface area (SSA), pores volume $\left(\mathrm{V}_{\text {pore }}\right)$ and average pores size $\left(\mathrm{D}_{\text {pore }}\right)$ of the samples supported on $\gamma-\mathrm{Al}_{2} \mathrm{O}_{3}$ and $\mathrm{CeO}_{2}$ are very close to that of the parent oxides (Table 2). A slight decrease of SSA was found for mixed $\mathrm{CeO}_{2}-\mathrm{Al}_{2} \mathrm{O}_{3}$ and $\mathrm{Y}$-doped $\mathrm{CeO}_{2}-\mathrm{Al}_{2} \mathrm{O}_{3}$, related mainly to the mechanical mixing of high surface area alumina $\left(200 \mathrm{~m}^{2} / \mathrm{g}\right)$ with $30 \mathrm{wt} . \%$ ceria with significantly lower specific surface area $\left(63 \mathrm{~m}^{2} / \mathrm{g}\right)$. The average pore diameter and pore volume were also slightly affected. Our recent studies of the impact of the preparation method of $\mathrm{CeO}_{2}-\mathrm{Al}_{2} \mathrm{O}_{3}$ mixed oxides on the textural properties indicated, that impregnation caused almost twice lowering of the specific surface areas and pore volume of the samples with the same composition in comparison with bare $\gamma-\mathrm{Al}_{2} \mathrm{O}_{3}$. These changes resulted from the deep penetration of $\mathrm{Ce}^{3+}$ ions in the pores of alumina [15]. The formation of ceria crystallites inside the pores limited to some extend the access of reactant to the active sites and affected catalytic activity. Having in mind these findings we selected mechnochemically prepared alumina-supported ceria as support of Pd catalysts.

Table 2: Textural characteristics, average particle size and cell parameter of $\mathrm{CeO}_{2}$ estimated by PXRD.

\begin{tabular}{|l|c|c|c|c|c|}
\hline Sample & $\begin{array}{c}\mathbf{S S A} \\
\mathbf{\mathbf { m } ^ { 2 }} / \mathbf{g}\end{array}$ & $\begin{array}{c}\mathbf{V}_{\text {pore }} \\
\mathbf{\mathbf { c m } ^ { 3 } / \mathbf { g }}\end{array}$ & $\begin{array}{c}\mathbf{D}_{\text {pore }} \\
\mathbf{n m}\end{array}$ & $\begin{array}{c}\mathbf{D}_{\text {ceria }} \\
\mathbf{n m}\end{array}$ & $\begin{array}{c}\boldsymbol{\alpha}_{\text {ceria }} \\
\mathbf{n m}\end{array}$ \\
\hline$\gamma-\mathrm{Al}_{2} \mathrm{O}_{3}$ & 200 & 0.53 & 10.6 & - & - \\
\hline $\mathrm{CeO}_{2}$ & 63.0 & 0.29 & 20.3 & 6.3 & $0.5424(2)$ \\
\hline $\mathrm{CeO}_{2}-\mathrm{Al}_{2} \mathrm{O}_{3}$ & 165.0 & 0.39 & 9.5 & 6.1 & $0.5422(1)$ \\
\hline $\mathrm{Y}-\mathrm{CeO}_{2}-\mathrm{Al}_{2} \mathrm{O}_{3}$ & 168.0 & 0.43 & 10.0 & 6.1 & $0.5421(2)$ \\
\hline $\mathrm{Pd} / \mathrm{Al}_{2} \mathrm{O}_{3}$ & 195.8 & 0.52 & 9.7 & - & - \\
\hline $\mathrm{Pd} / \mathrm{CeO}_{2}$ & 67.6 & 0.28 & 16.5 & 6.2 & $0.5424(4)$ \\
\hline $\mathrm{Pd} / \mathrm{CeO}_{2}-\mathrm{Al}_{2} \mathrm{O}_{3}$ & 161.2 & 0.45 & 9.5 & 5.8 & $0.5424(1)$ \\
\hline $\mathrm{Pd} / \mathrm{Y}-\mathrm{CeO}_{2}-\mathrm{Al}_{2} \mathrm{O}_{3}$ & 166.4 & 0.40 & 9.6 & 5.8 & $0.5420(1)$ \\
\hline
\end{tabular}

The PXRD patterns of supports and supported Pd samples are shown in Fig. 2. In the diffractograms of all Cecontaining samples reflections at $2 \theta=28.5^{\circ}, 33.1^{\circ}, 47.6^{\circ}, 56.4^{\circ}$, related to $(111),(200),(220)$ and (311) planes of the ceria phase in the cubic crystal structure of fluorite type were observed. The patterns were very similar in terms of the peak position and intensity. The average size of ceria particles $\left(\mathrm{D}_{\text {ceria }}\right)$ was calculated according to Scherrer's equation using FWHM of the peak at $2 \theta=28.5^{\circ}$ (Table 2). It was quite similar, in the range 5.8-6.3 nm. Very weak contribution of $\mathrm{Al}_{2} \mathrm{O}_{3}$ was visible at about $2 \theta=38^{\circ}$, as well as a broadening of the ceria peak at $2 \theta=47.6^{\circ}$. Reflections due to the presence of $\mathrm{Y}_{2} \mathrm{O}_{3}$ phase were not detected. The analysis revealed that the deposition of $\mathrm{Pd}$ and second thermal treatment at $400{ }^{\circ} \mathrm{C}$ affected neither particle size nor unit cell parameter of ceria $\left(\alpha_{\text {ceria }}\right)$. The absence of any palladium related phase should be attributed to its small content and high dispersion.

The results from XP spectral analysis are shown in Table 3. The binding energy (BE) of Al $2 p$ peak is not listed, because it was located at $75.1 \pm 0.1 \mathrm{eV}$ in the spectra of all samples. Components at $\mathrm{BE}$ around $336.7 \pm 0.1 \mathrm{eV}$, typical of $\mathrm{Pd}^{2+}$ were registered in the $\mathrm{Pd} 3 \mathrm{~d}_{5 / 2}$ spectra of Pd-based samples. Important information was provided by XPS derived $\mathrm{Pd} /(\mathrm{Ce}+\mathrm{Al})$ atomic ratio. Higher values, namely 0.044 and 0.041 , as compared to the analytical value of 0.006 were observed for $\mathrm{Pd} / \mathrm{CeO}_{2}-\mathrm{Al}_{2} \mathrm{O}_{3}$ and $\mathrm{Pd} / \mathrm{Y}-\mathrm{CeO}_{2}-\mathrm{Al}_{2} \mathrm{O}_{3}$. These ratios indicate a better surface dispersion of palladium. The much higher atomic ratio of 0.14 obtained for $\mathrm{Pd} / \mathrm{CeO}_{2}$ reflects the lower surface area of the support, maximising the Pd photoelectrons with respect to the support $\mathrm{Ce}$, but it is in accord with the role of ceria in favoring a high dispersion of the supported noble metals. 


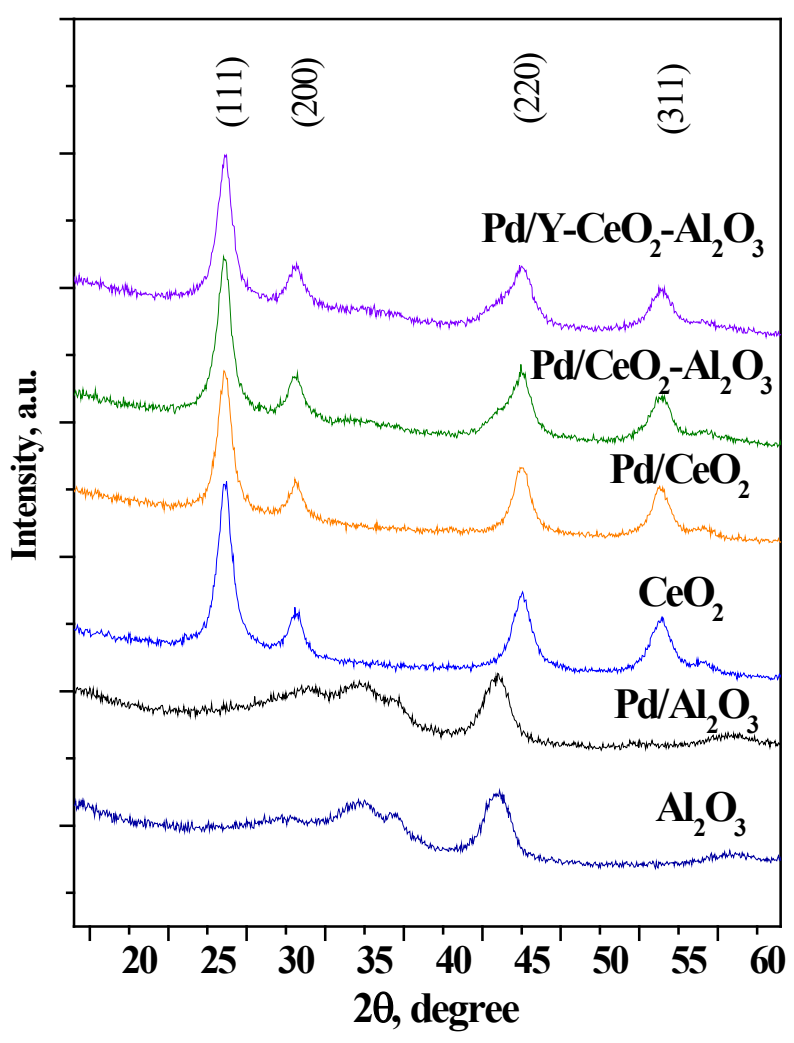

Fig. 2: PXRD patterns of the studied samples.

Both $\mathrm{Ce}^{4+}$ and $\mathrm{Ce}^{3+}$ oxidation states were detected in the $\mathrm{Ce} 3 \mathrm{~d}$ spectra of all Ce-containing samples. The atomic ratios $\mathrm{Ce}^{3+} /\left(\mathrm{Ce}^{4+}+\mathrm{Ce}^{3+}\right)$ were calculated, following the consensus about the relationship between the concentration of $\mathrm{Ce}^{3+}$ and oxygen vacancies formed for the charge compensation. The values were in the interval $0.25-0.38$, i.e. higher than the typically calculated values of $0.06-0.10$ for bulk ceria [16]. These results revealed the existence of defective ceria structure with oxygen vacancies formation on the catalyst surface.

The Y $3 \mathrm{~d}$ spectrum of the Y-containing sample was characterised by the $\mathrm{Y} 3 \mathrm{~d}_{5 / 2}$ binding energy of $157.8 \mathrm{eV}$ assigned to $\mathrm{Y}^{3+}$. The effect of $\mathrm{Y}$-doping on defectivity of ceria was clearly demonstrated. The effect was well visible by comparing the values of $\mathrm{Ce}^{3+} /\left(\mathrm{Ce}^{4+}+\mathrm{Ce}^{3+}\right)$ for $\mathrm{Pd} / \mathrm{Y}-\mathrm{CeO}_{2}-\mathrm{Al}_{2} \mathrm{O}_{3}(0.38)$ and undoped $\mathrm{Pd} / \mathrm{CeO}_{2}-\mathrm{Al}_{2} \mathrm{O}_{3}(0.25)$.

Table 3: X-ray photoelectron spectral analysis

\begin{tabular}{|c|c|c|c|c|}
\hline Sample & $\begin{array}{l}\text { Ce 3d } 5 / 2 \\
\text { BE }(e V)\end{array}$ & $\begin{array}{l}\text { Pd 3d } 5 / 2 \\
\text { BE }(e V)\end{array}$ & $\mathrm{Pd} /(\mathbf{C e}+\mathrm{Al})$ & $\mathrm{Ce}^{3+} /\left(\mathrm{Ce}^{3+}+\mathrm{Ce}^{4+}\right)$ \\
\hline $\mathrm{Pd} / \mathrm{Al}_{2} \mathrm{O}_{3}$ & - & 336.7 & $0.017(0.048)^{*}$ & - \\
\hline $\mathrm{Pd} / \mathrm{CeO}_{2}$ & 881.7 & 336.8 & $0.140(0.0163)^{*}$ & 0.35 \\
\hline $\mathrm{Pd} / \mathrm{CeO}_{2}-\mathrm{Al}_{2} \mathrm{O}_{3}$ & 881.8 & 336.6 & $0.044(0.0062)^{*}$ & 0.25 \\
\hline $\mathrm{Pd} / \mathrm{Y}-\mathrm{CeO}_{2}-\mathrm{Al}_{2} \mathrm{O}_{3}$ & 881.8 & 336.7 & $0.041(0.0063)^{*}$ & 0.38 \\
\hline
\end{tabular}

* values in brackets refer to analytical ratio 
The reducibility was evaluated by TPR with hydrogen. In Fig. 4 are presented TPR profiles of the samples. The profile of $\mathrm{Pd} / \mathrm{Al}_{2} \mathrm{O}_{3}$ sample contained a weak symmetric peak centered at $21{ }^{\circ} \mathrm{C}$. This peak was attributed to the reduction of PdO to $\mathrm{Pd}^{0}$ (the presence of $\mathrm{Pd}^{2+}$ was shown by XPS), because alumina is nonreducible oxide. Two peaks were observed in the profiles of ceria-containing samples. It is already well known that the reduction of ceria proceeds in two steps: the reduction of the surface layers at around $500{ }^{\circ} \mathrm{C}$ and the bulk reduction at higher temperatures (over $800{ }^{\circ} \mathrm{C}$ ) [17]. Noble metals significantly facilitate ceria surface layer reduction and boost the first reduction peak to much lower temperatures [5]. The narrow peaks in the interval $44-60{ }^{\circ} \mathrm{C}$ were attributed to the redox transfer $\mathrm{PdO} \leftrightarrow \mathrm{Pd}^{0}$ and some oxygen atoms from ceria surface layers in close vicinity to $\mathrm{Pd}$ particles. The broad peaks in the temperature range $300-500{ }^{\circ} \mathrm{C}$ corresponded to the further ceria surface reduction. The lowest peak intensity was observed in the profile of the catalyst with $30 \mathrm{wt} . \% \mathrm{CeO}_{2}$ on alumina. Doping of ceria by yttrium affected oxygen mobility and caused improved reducibility of $\mathrm{Pd} / \mathrm{Y}-\mathrm{CeO}_{2}-\mathrm{Al}_{2} \mathrm{O}_{3}$. Reasonably, the highest peak intensity was registered in the profile of the sample with the highest ceria amount, i.e. $\mathrm{Pd} / \mathrm{CeO}_{2}$.

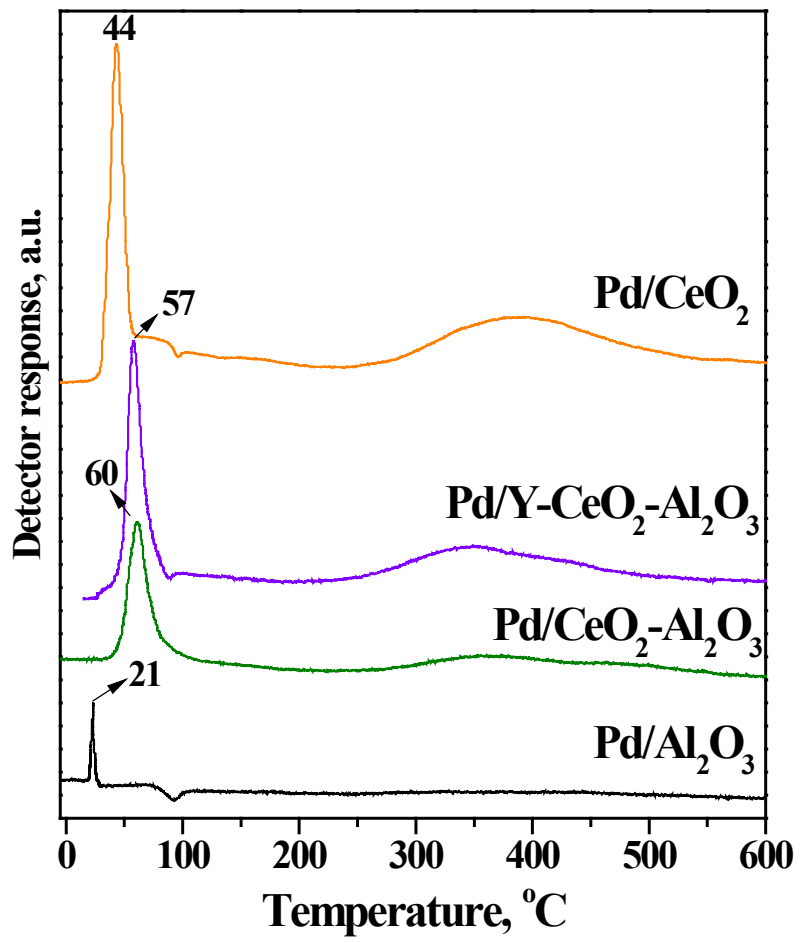

Fig. 4: TPR profiles of the studied catalysts.

EPR measurements were carried out over selected samples after catalytic tests aiming to shed more insight on the oxidation activity. The purpose of the EPR study was to detect eventual coke formation on the catalyst surface. The spectrum of $\mathrm{Pd} / \mathrm{CeO}_{2}$ is shown in Fig. 5 because this sample demonstrated lower activity in comparison with the other samples. A single EPR line with $g$ factor 2.003, which is characteristic of carbon-centered radical and coke, was recorded. Another line related to carbon-centered radicals with g-value of 2.0023 was registered in the EPR spectrum of the bestperforming $\mathrm{Pd} / \mathrm{Y}-\mathrm{CeO}_{2}-\mathrm{Al}_{2} \mathrm{O}_{3}$. This line is typical for free electrons [18]. Additionally, two EPR lines with $\mathrm{g}$ values 2.0249 and 2.0054 were observed in the spectrum of $\mathrm{Pd} / \mathrm{Y}-\mathrm{CeO}_{2}-\mathrm{Al}_{2} \mathrm{O}_{3}$, indicating a presence of oxygen species. Well defined line at magnetic field (334-335 mT) with g-value 1.964, assigned to $\mathrm{Ce}^{3+}$ was also observed, focusing on the possible role of $\mathrm{Ce}^{3+}$ in oxygen activation [19]. It is important to underline that such line was not detected in the spectrum of $\mathrm{Pd} / \mathrm{CeO}_{2}$. This finding reveals that the modification of commercial alumina by highly dispersed ceria nanoparticles using mechanochemical mixing is a promising approach in the design of catalytic materials with high efficiency in VOCs elimination. 


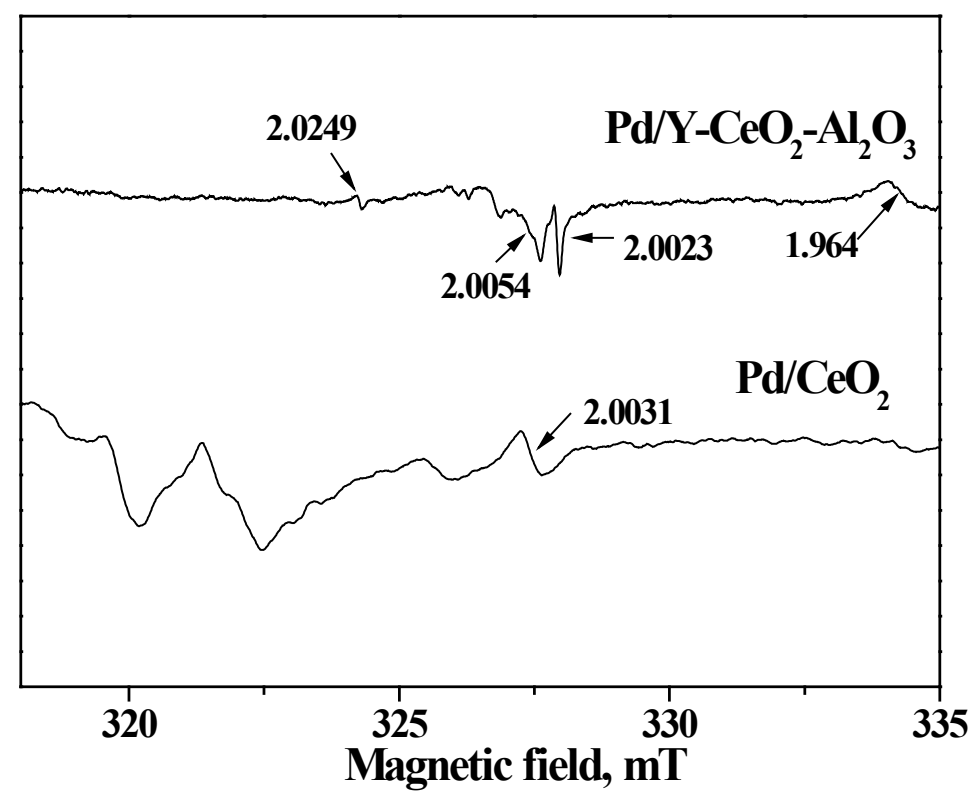

Fig. 5: EPR spectra of $\mathrm{Pd} / \mathrm{CeO}_{2}$ and $\mathrm{Pd} / \mathrm{Y}-\mathrm{CeO}_{2}-\mathrm{Al}_{2} \mathrm{O}_{3}$ catalysts.

\section{Conclusion}

The effect of the nature of support on the performance of supported Pd catalysts for CBO was studied. Two metal oxides, namely $\mathrm{Al}_{2} \mathrm{O}_{3}$ and $\mathrm{CeO}_{2}$ were selected. Aiming the developing of cost effective catalytic materials with improved efficiency in the elimination of VOCs, alumina-supported ceria and Y-doped ceria were prepared by mechanochemical mixing. Pd-based sample on alumina-supported Y-doped ceria exhibited the highest activity. The best performance of $\mathrm{Pd} / \mathrm{Y}-\mathrm{CeO}_{2}-\mathrm{Al}_{2} \mathrm{O}_{3}$ catalyst was related to the redox transfer $\mathrm{Pd}^{0} \leftrightarrow \mathrm{PdO}$, better surface dispersion of palladium and high atomic ratio $\mathrm{Ce}^{3+} /\left(\mathrm{Ce}^{4+}+\mathrm{Ce}^{3+}\right)$ revealed by XPS analysis. The registration of line with g-value 1.964 assigned to $\mathrm{Ce}^{3+}$ in the EPR spectrum of the most active catalyst after catalytic test implied the beneficial role of surface modification of alumina with highly despersed fraction of $\mathrm{Y}$-doped ceria. Taking into account high activity of $\mathrm{Pd} / \mathrm{Al}_{2} \mathrm{O}_{3}$, it was suggested that the superior activity of $\mathrm{Pd} / \mathrm{Y}-\mathrm{CeO}_{2}-\mathrm{Al}_{2} \mathrm{O}_{3}$ originated from contribution to the oxidation activity of both $\mathrm{Pd}$ located on ceria or $\mathrm{Y}$-doped ceria phase and $\mathrm{Pd}$ dispersed on alumina. The potential of this catalytic material to meet emission regulations in an effective and economically profitable way was demonstrated.

\section{Acknowledgements}

Authors affiliated at Institute of Catalysis-BAS gratefully acknowledge the financial support by Bulgarian National Science Fund (grant number КП-06-KОСТ/4/2018). This article is based upon work from COST Action INDAIRPOLLNET CA17136, supported by COST (European Cooperation in Science and Technology).

\section{References}

[1] M. S. Kamal, S. A. Razzak, M. M. Hossain, "Catalytic oxidation of volatile organic compounds (VOCs) A review," Atmos. Environ., vol. 140, pp. 117-134, 2016.

[2] C. He, J. Cheng, X. Zhang, M. Douthwaite, S. Pattisson, Z. Hao, "Recent advances in the catalytic oxidation of volatile organic compounds: A review based on pollutant sorts and sources," Chem. Rev., vol. 119, pp. 4471-4568, 2019. 
[3] T. Gelles, A. Krishnamurthy, B. Adebayo, A. Rownaghi, F. Rezaei, "Abatement of gaseous volatile organic compounds: A material perspective," Catal. Today, vol. 350, pp. 3-18, 2020.

[4] J. Li, H. Liu, Y. Deng, G. Liu, Y. Chen, J. Yang, "Emerging nanostructured materials for the catalytic removal of volatile organic compounds," Nanotechn. Rev., vol. 5, pp. 147-181, 2016.

[5] L. F. Liotta, "Catalytic oxidation of volatile organic compounds on supported noble metals," Appl. Catal. B Environ., vol. 100, pp. 403-412, 2010.

[6] S. C. Kim and W. G. Shim, "Properties and performance of Pd based catalysts for catalytic oxidation of volatile organic compounds," Appl. Catal. B Environ., vol. 92, pp. 429-436, 2009.

[7] S. Song, S. Zhang, X. Zhang, P. Verma, M. Wen, "Advances in catalytic oxidation of Volatile organic compounds over Pd-supported catalysts: Recent trends and challenges," Front. Mater., vol. 7, article 595667, 2020.

[8] G. Centi, "Supported palladium catalysts in environmental catalytic technologies for gaseous emissions", J. Mol. Catal. A Chem. Vol. 173, pp. 287-312, 2001.

[9] J. Liu, Y. Chen, H. Wang, M. Yang, Y. Wu, Z. Chen, "Effects of atmosphere pretreatment on the catalytic performance of $\mathrm{Pd} / \gamma-\mathrm{Al}_{2} \mathrm{O}_{3}$ catalyst in benzene degradation II: Crystal structure transformation of Pd active species," Catal. Today, vol. 297, pp. 211-218, 2017.

[10] X. Weng, B. Shi, A. Liu, J. Sun, Y. Xiong, H. Wan, S. Zheng, L. Dong, Y. -W. Chen, "Highly dispersed Pd/modified$\mathrm{Al}_{2} \mathrm{O}_{3}$ catalyst on complete oxidation of toluene: Role of basic sites and mechanism insight," Appl. Surf. Sci., vol. 497 , $143747,2019$.

[11] S. Gil, J. Garcia-Vargas, L. Liotta, G. Pantaleo, M. Ousmane, L. Retailleau, A. Giroir-Fendler, "Catalytic oxidation of propene over Pd catalysts supported on $\mathrm{CeO}_{2}, \mathrm{TiO}_{2}, \mathrm{Al}_{2} \mathrm{O}_{3}$ and $\mathrm{M} / \mathrm{Al}_{2} \mathrm{O}_{3}$ oxides $(\mathrm{M}=\mathrm{Ce}$, Ti, $\mathrm{Fe}, \mathrm{Mn})$," Catalysts, vol. 5, pp. 671-689, 2015.

[12] S. Ren, W. Liang, Q. Li, Y. Zhu, "Effect of $\mathrm{Pd} / \mathrm{Ce}$ loading on the performance of $\mathrm{Pd}-\mathrm{Ce} / \gamma-\mathrm{Al}_{2} \mathrm{O}_{3}$ catalysts for toluene abatement," Chemosphere, vol. 251, 126382, 2020.

[13] L. Ilieva, A. M. Venezia, P. Petrova, G. Pantaleo, L. F. Liotta, R. Zanella, Z. Kaszkur, T. Tabakova, "Effect of Y modified ceria support in mono and bimetallic Pd-Au catalysts for complete benzene oxidation," Catalysts, vol. 8, pp. 283, 2018.

[14] C. He, J. Li, P. Li, J. Cheng, Z. Hao, Z.-P. Xu, "Comprehensive investigation of Pd/ZSM-5/MCM-48 composite catalysts with enhanced activity and stability for benzene oxidation," Appl. Catal. B Environ., vol. 96, pp. 466-475, 2010.

[15] T. Tabakova, I. Ivanov, R. Zanella, Y. Karakirova, J W. Sobczak, W. Lisowski, Z. Kaszkur, L. Ilieva, "Unraveling the effect of alumina-supported Y-doped ceria composition and method of preparation on the WGS activity of gold catalysts," Int. J. Hydrogen Energy, vol. 45, no. 49, pp. 26238-26253, 2020.

[16] L. F. Liotta, G. Pantaleo, F. Puleo, A. M. Venezia, "Au/CeO ${ }_{2}-\mathrm{SBA}-15$ catalysts for $\mathrm{CO}$ oxidation: Effect of ceria loading on physicochemical properties and catalytic performances," Catal. Today, vol. 187, pp. 10-19, 2012.

[17] H. C. Yao, Y. F. Y. Yao, "Ceria in automotive exhaust catalysts: I. Oxygen storage," J. Catal., vol. 86, pp. 254-265, 1984.

[18] U. Green, Z. Aizanshtat, S. Ruthstein, H. Cohen, "Stable radicals formation in coals undergoing weathering: Effect of coal rank," Phys. Chem. Chem. Phys., vol. 14, pp. 13046-1305, 2012.

[19] L. Ge, T. Chen, Z. Liu, F. Chen, "The effect of gold loading on the catalytic oxidation performance of $\mathrm{CeO}_{2} / \mathrm{H}_{2} \mathrm{O}_{2}$ system," Catal. Today, vol. 224, pp. 209-215, 2014. 